\title{
Nitrogen dynamics of eelgrass Zostera marina during a late summer period of high growth and low nutrient availability*
}

\author{
Morten Foldager Pedersen, Jens Borum \\ Freshwater-Biological Laboratory, University of Copenhagen, Helsingørsgade 51, DK-3400 Hillerød, Denmark
}

\begin{abstract}
Nitrogen acquisition and dynamics of eelgrass Zostera marina L. were assessed during a late summer period of high plant growth and low nitrogen availability in the water column. Nitrogen uptake through leaves and roots, translocation within the plant, and the role of nitrogen reclamation from older plant parts were estimated using ${ }^{15} \mathrm{~N}$-techniques and compared to nitrogen incorporation in growing tissues. Total eelgrass biomass was $700 \mathrm{~g}$ (dry wt) $\mathrm{m}^{-2}$ Relative growth rate was $0.022 \mathrm{~d}^{-1}$ and eelgrass production was $5.6 \mathrm{~g} \mathrm{C} \mathrm{m}^{-2} \mathrm{~d}^{-1}$ Production was high in spite of low nitrogen availability in the water column and low internal nitrogen contents of plants. Nitrogen incorporation in growing tissues was $0.155 \mathrm{~g} \mathrm{~N} \mathrm{~m}^{-2} \mathrm{~d}^{-1}$, and the molar ratio of incorporated $\mathrm{C}$ to $\mathrm{N}(\mathrm{C}: \mathrm{N})$ was 42 or 6 -fold higher than the average ratio reported for phytoplankton. However, due to efficient translocation of nitrogen from old to young tissues, $\mathrm{C}: \mathrm{N}$ in the most actively growing leaf was only 2 -fold higher than that of phytoplankton. Reclamation of nitrogen from old tissues supplied $12 \%$ of total nitrogen incorporation and $88 \%$ was supplied by external media uptake. Leaf and root uptake were equally important in spite of much higher nitrogen availability in the sediment porewater compared to that of the water column. Eelgrass seems well adapted to nitrogen-poor environments because it conserves nitrogen within the plant, efficiently takes up nitrogen from both the water column and sediment, maintains high growth rates in spite of low internal nitrogen contents.
\end{abstract}

\section{INTRODUCTION}

Nutrient availability is potentially a limiting factor to the production and biomass accumulation of aquatic phototrophs. Phytoplankton, periphytic microalgae and fast-growing ephemeral macroalgae are often limited by low nutrient availability, while slowgrowing perennial macroalgae and rooted macrophytes seem less dependent on nutrient richness (Sand-Jensen \& Borum 1991). The temperate seagrass, eelgrass Zostera marina L., can sustain high rates of primary production during periods of low nutrient availability in the water column. Maximum rates of production are found during summer (exceeding $5 \mathrm{~g}$ $\mathrm{C} \mathrm{m}^{-2} \mathrm{~d}^{-1}$; Sand-Jensen 1975, Jacobs 1979, WiumAndersen \& Borum 1984, Pedersen 1990) and are up to 10 -fold higher than rates of open water phytoplankton production. According to the Redfield $\mathrm{C}: \mathrm{N}$ ratio

\footnotetext{
- Contribution No. 541 of the Freshwater-Biological Laboratory, University of Copenhagen
}

[106: $16=6.6$ (molar); Redfield et al. 1963] the nitrogen requirement for phytoplankton production is $0.18 \mathrm{~g} \mathrm{~N}$ ( $\mathrm{g} \mathrm{C}^{-1}$. Although one might expect that all actively growing plant cells should contain about the same amount of nitrogen relative to carbon, the nitrogen concentration in marine macrophytes is substantially lower than in phytoplankton $(\mathrm{C}: \mathrm{N}=18$ to 22 ; Atkinson \& Smith 1984, Duarte 1990). However, nitrogen requirement for maximum eelgrass production per $\mathrm{m}^{2}$ is still 3-fold higher than that for phytoplankton production.

In oligotrophic and mesotrophic freshwaters, rooted macrophytes take up most of their nutrients from the sediment (Carignan \& Kalff 1980, Barko \& Smart 1981). Eelgrass takes up nitrogen from both the water column and the sediment (Iizumi \& Hattori 1982, Thursby \& Harlin 1982, Short \& McRoy 1984). Leaves have higher uptake affinity per dry wt than roots-rhizomes (Short \& McRoy 1984), but nitrogen availability is generally much higher in sediment than in the water column (e.g. Iizumi \& Hattori 1982, Boon 1986, Dennison et al. 1987) and, therefore, sediment might be expected to 
be the primary nutrient source. However, estimates of total nitrogen uptake suggest that both leaves and roots-rhizomes contribute significantly to the nitrogen acquisition of eelgrass (Iizumi \& Hattori 1982, Short \& McRoy 1984, Zimmerman et al. 1987).

Nitrogen taken up from the external media is translocated from leaves to roots and vice versa (Iizumi \& Hattori 1982), and translocation also occurs among different leaves (Borum et al. 1989). Borum et al. (1989) suggested that nitrogen uptake rates in leaves were independent of leaf age, and that old leaves function as organs of efficient nutrient uptake. Old leaves do not grow but translocate surplus nitrogen to younger, actively growing tissues and help to meet the nutrient requirement of the whole plant. Furthermore, Jensen (1915) observed a gradual decrease in the nitrogen content of eelgrass leaves with increasing leaf age, and Patriquin (1972) suggested that reclamation (resorption) of nutrients from old leaves could be an important nutrient-conserving mechanism for seagrasses. A culture experiment with ${ }^{15} \mathrm{~N}$-labelled eelgrass plants showed that nitrogen can potentially be reclaimed from old leaves and translocated to actively growing young tissues, reducing the need for external nitrogen supply (Borum et al. 1989).

Several questions emerge from these observations: how and from which sources is the high nitrogen requirement of eelgrass met during periods of low nutrient availability in the water column; how important is reclamation as a nutrient-conserving mechanism; and how can eelgrass sustain high rates of growth when internal concentrations of nutrients are much lower than in phytoplankton cells? In the present paper we focus on nitrogen because phosphorus seems less limiting than nitrogen in coastal Danish waters (Sand-Jensen \& Borum 1991).

The objective of the present investigation was to describe nitrogen acquisition and dynamics of eelgrass under in situ conditions during a late summer period of high plant growth and low nitrogen availability in the water column. We measured eelgrass biomass and growth, nitrogen content and incorporation, and external nitrogen availability. Nitrogen uptake, translocation and reclamation were estimated using ${ }^{15} \mathrm{~N}$ techniques under in situ conditions. We calculated nitrogen uptake in leaves vs roots-rhizomes and subsequent nitrogen translocation to actively growing tissues, and estimated the role of nitrogen conservation relative to that of the external nitrogen supply.

\section{MATERIALS AND METHODS}

Study area. The study was conducted in a homogeneous eelgrass stand at Hvidøre, Oresund, Denmark [the same site used by Wium-Andersen \& Borum (1984)] during the period from 5 July to 15 August 1988. Mean water depth was $1.0 \mathrm{~m}$ (range: 0.7 to $1.3 \mathrm{~m}$ ) and the sediment consisted of coarse-grained sand. Water temperature was 18.0 to $19.1^{\circ} \mathrm{C}$ and salinity 11 to $12 \%$.

Nitrogen in water, sediment and plant tissues. Inorganic nitrogen concentration in the water was measured 4 times and in the sediment porewater twice during the study. Water samples were collected in triplicate and analyzed for $\mathrm{NH}_{4}{ }^{+}$(Solorzano 1969) and $\mathrm{NO}_{3}{ }^{-}$(Strickland \& Parsons 1968). Concentration of $\mathrm{NH}_{4}{ }^{+}$in the porewater was measured on sediment cores taken down to $10 \mathrm{~cm}$ depth corresponding to the maximum depth of eelgrass roots. Porewater was obtained by filtration (Whatman GF/C) under pressure, and $\mathrm{NH}_{4}{ }^{+}$was analyzed according to Solorzano (1969).

Nitrogen content of different eelgrass tissues sampled in the field was measured twice during the study. At each date 9 intact terminal shoots were uprooted from the eelgrass population. Plants were separated into individual leaves (Nos. 1 to $b$ of increasıng age) that were carefully scraped free of epiphytes with a scalpel. Rhizomes were separated into 3 groups of internode segments: (R1 to 3 ) the first 3 rhizome segments, not fully grown and with sparse root development; ( $R 4$ to 7 ) the next 4 , fully grown and with living roots; (R8 to 11) the last 4 , still alive but with senescent root bundles. Individual leaves (e.g. all No.1 leaves) or groups of internode rhizome segments from 3 plants were pooled and treated as 1 set of samples in order to obtain enough plant material for analysis. All samples were analysed in triplicate. Plant material was dried, finely ground and analysed for carbon and nitrogen content on a Perkin-Elmer $240 \mathrm{C}$ elemental analyzer.

Eelgrass biomass, growth and nitrogen incorporation. Eelgrass biomass was obtained by harvesting all leaf and root-rhizome material within 4 to 5 randomly chosen quadrats $\left(0.12 \mathrm{~m}^{2}\right.$ each). Plant material was washed on a $2 \mathrm{~mm}$ sieve, and dead rhizomes and leaves were removed from the samples before being dried to constant weight at $80^{\circ} \mathrm{C}$. Leaf and root rhizome growth was assessed using the in situ leafmarking technique described by Sand-Jensen (1975). This technique provides information on growth of individual leaves in the eelgrass short shoot.

Nitrogen incorporation for eelgrass growth was calculated as the product of leaf or root-rhizome production and nitrogen content of almost fully grown leaves (Leaf No. 3) or roots-rhizomes (R4 to 7).

Nitrogen uptake through leaves vs roots. Leaf vs root uptake of inorganic nitrogen was assessed by applying a technique similar to that used for phosphorus uptake in freshwater macrophytes (Carignan \& 
Kalff 1980). Sediment collected at the study site was enriched with ${ }^{15} \mathrm{NH}_{4} \mathrm{Cl}$, thoroughly homogenized, and allowed to equilibrate for $5 \mathrm{wk}$. Intact eelgrass plants were marked on the leaves with a felt pen to measure leaf growth and were individually planted in 0.51 polyethylene bottles containing ${ }^{15} \mathrm{~N}$-enriched or unenriched (controls) sediment. The bottles were closed with foam rubber seals and placed on the sediment within the eelgrass population in the field. Plants were harvested after $10 \mathrm{~d}$ (corresponding to the appearance of approximately 1 new leaf) and analysed for ${ }^{14} \mathrm{~N}$ and ${ }^{15} \mathrm{~N}$. Sediment samples were collected from the bottles before and after the growth experiment and analysed for ${ }^{14} \mathrm{NH}_{4}{ }^{+}$and ${ }^{15} \mathrm{NH}_{4}{ }^{+}$in the porewater. The contents of ${ }^{15} \mathrm{~N}$ in plant tissues and extracted porewater ammonia were measured in a V.G. Isogas Chaschera Sera series 2 mass spectrometer connected to a Carlo Erba 1500 elemental analyzer.

Nitrogen uptake through leaves and roots was also calculated using the uptake kinetics described by Iizumi \& Hattori (1982) and based on ambient concentrations of $\mathrm{NH}_{4}{ }^{+}$and $\mathrm{NO}_{3}{ }^{-}$in the water phase and $\mathrm{NH}_{4}{ }^{+}$ concentration in the sediment porewater of the eelgrass bed. Iizumi \& Hattori (1982) expressed uptake rates in $\mu \mathrm{g} \mathrm{N}$ ( $g$ tissue $\mathrm{N})^{-1} \mathrm{~d}^{-1}$ and these were transformed to $\mu \mathrm{g} \mathrm{N}$ (g dry $w t)^{-1} \mathrm{~d}^{-1}$ using information on nitrogen content in leaves and roots-rhizomes of their experimental plants [all rates in $\mu \mathrm{g} N(\mathrm{~g} d r y \mathrm{wt})^{-1} \mathrm{~d}^{-1}$ ]:

Leaf uptake, $\mathrm{NH}_{4}{ }^{+}=88.4 \times\left[\mathrm{NH}_{4}{ }^{+}\right]_{\text {water }}$

Leaf uptake,

$$
\mathrm{NO}_{3}{ }^{-}=1945 \times\left[\mathrm{NO}_{3}{ }^{-}\right]_{\text {water }} /\left(22.6+\left[\mathrm{NO}_{3}{ }^{-}\right]_{\text {water }}\right)
$$

Root uptake,

$$
\mathrm{NH}_{4}{ }^{+}=454 \times\left[\mathrm{NH}_{4}{ }^{+}\right]_{\text {sed }} /\left(30.5+\left[\mathrm{NH}_{4}{ }^{+}\right]_{\text {sed. }}\right)
$$

A third and final estimate was calculated from the ${ }^{15} \mathrm{~N}$ pre-incubation experiment described below

Nitrogen dynamics within eelgrass plants. Nitrogen dynamics within eelgrass were assessed using the ${ }^{15} \mathrm{~N}$ pre-incubation technique described by Borum et al. (1989). However, the present experiment was performed in situ after pre-incubation and for a longer period than used by Borum et al. (1989). Intact plants were uprooted and incubated in three $40 \mathrm{l}$ aquaria (30 plants in each) containing filtered (Whatman GF/C) seawater. Temperature was held constant at $16^{\circ} \mathrm{C}$, and a 16:8 h light:dark cycle was applied. The water was enriched with ${ }^{15} \mathrm{~N}\left(\mathrm{NH}_{4} \mathrm{Cl}, 99 \mathrm{dt} \%{ }^{15} \mathrm{~N}\right)$ to a concentration of $20 \mu \mathrm{M}$. Addition of ${ }^{15} \mathrm{~N}$ was repeated on Days 3 and 5. Control plants were incubated and treated as experimental plants but without addition of ${ }^{15} \mathrm{~N}$. After $7 \mathrm{~d}$ incubation, 9 control and 9 experimental plants ( 3 from each aquarium) were harvested for analysis of
${ }^{14} \mathrm{~N}$ and ${ }^{15} \mathrm{~N}$. Remaining plants were marked with a felt pen for growth measurements. Leaves older than No. 6 were removed, and the plants were transplanted into the eelgrass bed, still in 3 different groups and mixed with unlabelled control plants. After 10 and $27 \mathrm{~d}$, corresponding to the appearance of approximately 1 and 3 new leaves plant ${ }^{-1}$ (and loss of 1 and 3 old leaves), 9 labelled and 9 control plants were harvested. Leaf growth was recorded and converted to weight gain using the observed weight: length ratios for leaves of different age. Growth of roots-rhizomes was estimated assuming that exactly 1 or 3 new segments had been produced. All plants were separated into individual tissues, dried and prepared for $\mathrm{N}$-analysis as described above.

Translocation of total $\mathrm{N}$ from individual plant parts was calculated from the net loss of ${ }^{15} \mathrm{~N}$ during the incubation period in the field and from the average at. $\%{ }^{15} \mathrm{~N}$ excess in these tissues (Borum et al. 1989). Average at. $\%{ }^{15} \mathrm{~N}$ was calculated as the arithmetic mean of values measured at the beginning and end of the period assuming a linear decrease in at. $\%{ }^{15} \mathrm{~N}$ excess with time. Translocation to sink tissues was similarly calculated from net gains of ${ }^{15} \mathrm{~N}$ and average at. $\%{ }^{15} \mathrm{~N}$ excess in these tissues. Net changes in total $\mathrm{N}$ of individual plant parts, which were not explained by translocation, were balanced by assuming uptake from or loss (i.e. leaching) to the external media. These calculations were made for plants being incubated for 10 and $27 \mathrm{~d}$ in the field, and the data sets were combined to establish mass balances of ${ }^{15} \mathrm{~N}$ and total $\mathrm{N}$ covering the entire $27 \mathrm{~d}$ experimental period. Total nitrogen incorporation in the plant was calculated as cumulated net gains of plant-bound nitrogen, and reclamation of nitrogen was estimated as cumulated net losses from old tissues. When leaves changed position from No. 6 to No. 7 and when root-rhizome segments became older than segment No. 11, these tissues and their nitrogen contents were considered lost from the eelgrass shoot.

\section{RESULTS}

\section{Field data}

Eelgrass biomass was almost constant (694 to $715 \mathrm{~g}$ dry wt $\mathrm{m}^{-2}$ ) during the study, and roots-rhizomes accounted for about $40 \%$ of total biomass (Table 1 ). Integrated leaf and root-r hizone production was $627 \mathrm{~g}$ dry w $\mathrm{m}^{-2}$ corresponding to a daily production rate of 15.3 g dry wt $\mathrm{m}^{-2}$ (5.6 $\mathrm{g} \mathrm{C} \mathrm{m}^{-2}$ ) or a relative growth rate of $0.022 \mathrm{~d}^{-1}$. Nitrogen availability was relatively low in the water column (3.6 to $6.1 \mu \mathrm{M}$ inorg. $N$ ) but high in the sediment porewater ( 430 to $462 \mu \mathrm{M} \mathrm{NH}{ }_{4}{ }^{+}-\mathrm{N}$ ). Eel- 
Table 1. Zostera marina. Eelgrass biomass and production measured in the field from 5 July to 15 August 1988 . C and $\mathrm{N}$ contents were measured in unmanipulated plants. Nitrogen incorporation was calculated from eelgrass production and elemental contents of fully grown leaves and roots-rhizomes

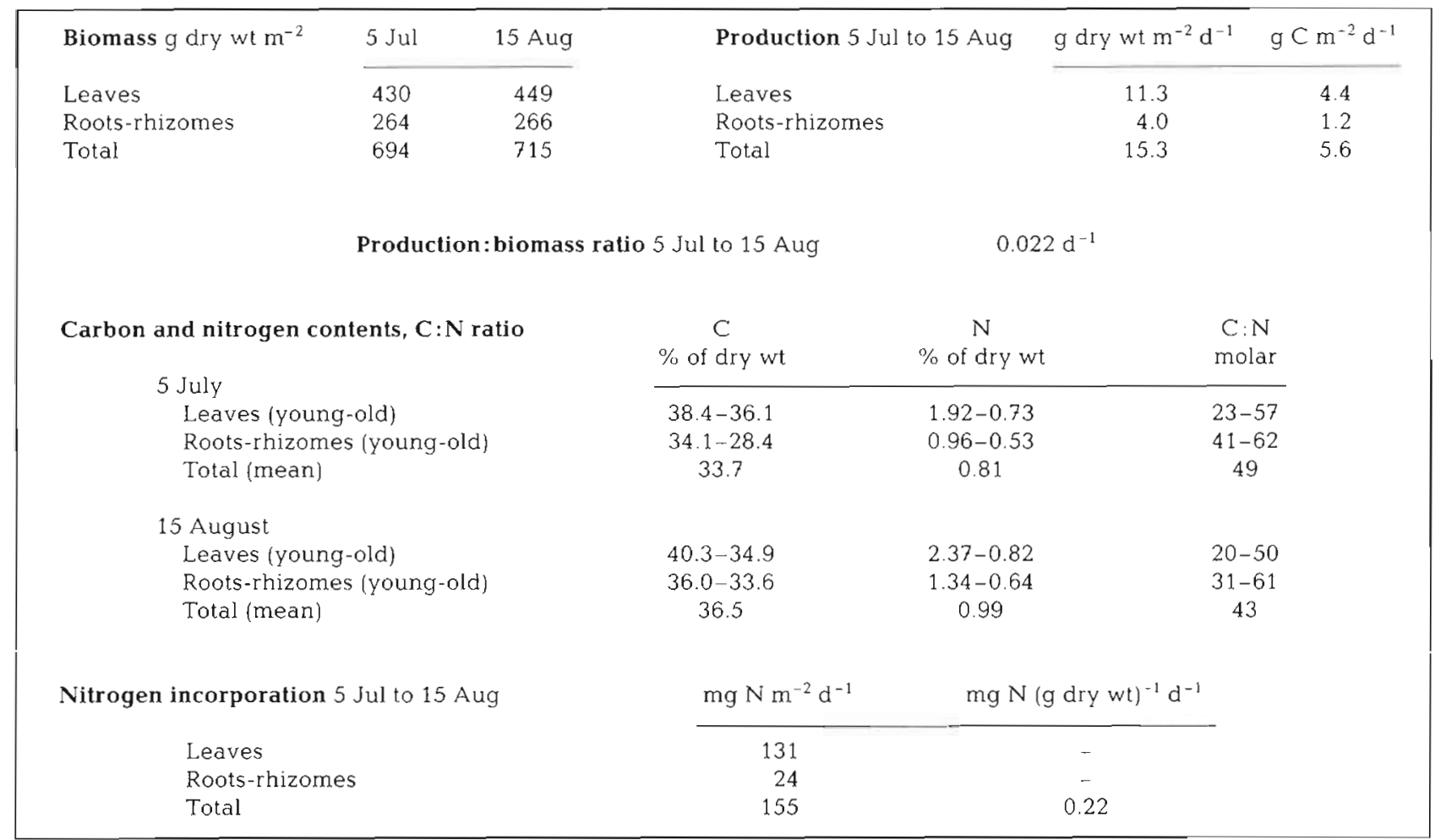

grass nitrogen content increased during the study (Fig. 1, Table 1). Nitrogen concentrations were high in the youngest and most actively growing tissues but declined in older tissues (Fig. 1). Nitrogen incorporation for eelgrass growth was $0.22 \mathrm{mg} \mathrm{N}$ (g dry wt) $)^{-1} \mathrm{~d}^{-1}$ or $0.155 \mathrm{~g} \mathrm{~N} \mathrm{~m}^{-2} \mathrm{~d}^{-1}$, and, hence, the $\mathrm{C}: \mathrm{N}$ ratio (molar) for eelgrass growth was 42 . Among leaves of different age, $\mathrm{C}: \mathrm{N}$ ratios varied from 20 in the youngest to above 50 in the oldest (Table 1 ). The $\mathrm{C}: \mathrm{N}$ ratio was generally higher in roots-rhizomes, ranging from 31 to 62

\section{Nitrogen uptake through leaves vs roots}

During the root-uptake experiment (Table 2), the relative growth rate of eelgrass was slightly lower $(0.020$ $\mathrm{d}^{-1}$ ) than measured in the natural population (Table 1), but nitrogen incorporation $[0.34 \mathrm{mg} \mathrm{N} \text { (g dry } w \mathrm{t})^{-1} \mathrm{~d}^{-1}$ ) was higher resulting in more nitrogen-rich plants. ${ }^{15} \mathrm{~N}$ was taken up from the sediment and mainly incorporated in the roots-rhizomes but $34 \%$ was translocated to the leaves. Control plants placed close to the experimental plants did not show any enrichment with ${ }^{15} \mathrm{~N}$ above natural levels indicating that ${ }^{15} \mathrm{~N}$ was not taken up by the leaves after having escaped the sediment. Of the total increase in plant-bound nitrogen $0.319 \%$ was accounted for by ${ }^{15} \mathrm{~N}$, and with an at. $\%{ }^{15} \mathrm{~N}$ excess of 0.734 in the sediment porewater $43.5 \%$ of total nitrogen incorporation was supplied from the sediment (Table 2).

Using the nitrogen uptake kinetics for leaves and roots described by lizumi \& Hattori (1982), total nitrogen uptake $\left[0.47 \mathrm{mg} N(\mathrm{~g} \text { dry } w \mathrm{t})^{-1} \mathrm{~d}^{-1}\right]$ substantially exceeded the incorporation estimated for in the field (Table 3). However, the relative contribution from the roots-rhizomes accounted for $60 \%$ of the total uptake Finally, according to data from the ${ }^{15} \mathrm{~N}$ pre-incubation experiment described below, the nitrogen incorporation for growth of experimental plants was $0.25 \mathrm{mg} \mathrm{N}$ $(\mathrm{g} d r y \mathrm{wt})^{-1} \mathrm{~d}^{-1}$ and roots-rhizomes only covered $24 \%$ of this incorporation (Table 3).

\section{Nitrogen dynamics within eelgrass}

During the ${ }^{15} \mathrm{~N}$ pre-incubation experiment plants were allowed to assimilate ${ }^{15} \mathrm{~N}-\mathrm{NH}_{4}{ }^{+}$in the laboratory, and since we did not use tracer concentrations, the nitrogen content of the plants increased markedly (Fig. 1B). Most of the incorporated ${ }^{15} \mathrm{~N}$ was found in the youngest leaves and rhizome segments but older tissues were also enriched. After $10 \mathrm{~d}$ growth in the 


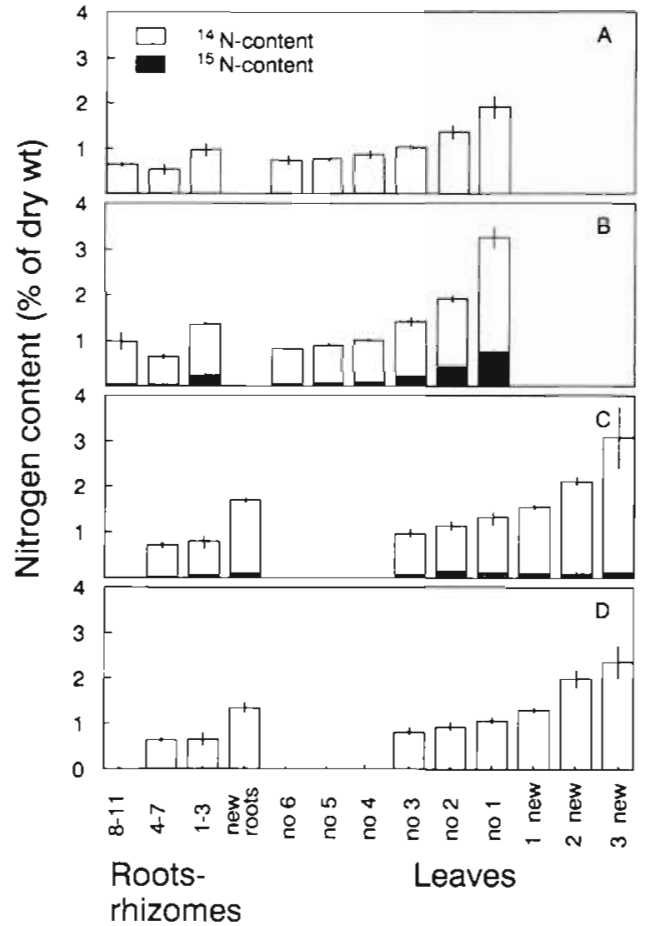

Fig. 1. Zostera marina. ${ }^{14} \mathrm{~N}$ and ${ }^{15} \mathrm{~N}$ contents of leaves and groups of root-rhizome segments in field and experimental eelgrass. (A) $\mathrm{N}$ content in field plants prior to experiment, (B) ${ }^{14} \mathrm{~N}$ and ${ }^{15} \mathrm{~N}$ in plants after $1 \mathrm{wk}$ of ${ }^{13} \mathrm{~N}$-pre-incubation in the laboratory, (C) ${ }^{14} \mathrm{~N}$ and ${ }^{15} \mathrm{~N}$ in manipulated plants after $27 \mathrm{~d}$ in the field, and (D) $\mathrm{N}$ content in unmanipulated field plants at the end of the experiment. The study period of $27 \mathrm{~d}$ corresponded to 3 plastochrone intervals. Vertical bars $=$ $\pm \mathrm{SD}(\mathrm{n}=3)$

field 1 new leaf had been produced (data not shown) and after $27 \mathrm{~d}$ growth 3 new leaves and rhizome segments had been produced (Fig. 1C). Relative growth rate of manipulated eelgrass in the field was $0.022 \mathrm{~d}^{-1}$, similar to that measured for unmanipulated plants (Table 1). Nitrogen content of the 2 youngest leaves and the oldest rhizome segments (Fig. 1C) was slightly lower than at the start of the incubation period but higher in all other tissues, resulting in a general increase in total nitrogen content of the plants. The ${ }^{15} \mathrm{~N}$ concentration decreased in all tissues due to 'dilution' in growing plant parts and translocation from old to young tissues (Fig. 1C). Control plants placed among the ${ }^{15} \mathrm{~N}$-enriched experimental plants were not detectably enriched with ${ }^{15} \mathrm{~N}$ meaning that ${ }^{15} \mathrm{~N}$ lost from a plant or leaf by leakage into the water column was not taken up by others. Thus, the observed mobility of ${ }^{15} \mathrm{~N}$ was solely due to internal translocation within plant parts.

A ${ }^{15} \mathrm{~N}$ mass balance over $27 \mathrm{~d}$ for an eelgrass plant is shown in Fig. 2. At the end of the experiment $59.9 \%$ of the shoot dry wt had been replaced by new
Table 2. Zostera marina. Leaf vs root uptake experiment Shoot weight, growth, nitrogen incorporation and incorporation of ${ }^{15} \mathrm{~N}$ (all per plant) in eelgrass incubated with ${ }^{15} \mathrm{~N}$ enriched sediment in the field. Incubation period was $10 \mathrm{~d}$ corresponding to the production of 1 new leaf

\begin{tabular}{|c|c|c|c|c|}
\hline & $\begin{array}{l}\text { hoot weight } \\
\text { (mg dwt) }\end{array}$ & $\begin{array}{l}\text { Growth } \\
\text { (mg dwt) }\end{array}$ & $\begin{array}{l}\text { Total N } \\
(\mu g N)\end{array}$ & $\begin{array}{l}{ }^{15} \mathrm{~N} \text { excess } \\
\left(\mu \mathrm{g}{ }^{15} \mathrm{~N}\right)\end{array}$ \\
\hline Leaves & 292 & 78 & 927 & 1.99 \\
\hline Roots-rhizomes & 240 & 30 & 886 & 3.80 \\
\hline Total plant & 532 & 108 & 1813 & 5.79 \\
\hline \multicolumn{4}{|c|}{ Relative growth rate } & $0.020 \mathrm{~d}^{-1}$ \\
\hline \multicolumn{4}{|c|}{ at. $\%{ }^{15} \mathrm{~N}$ excess of plant tissues } & 0.319 \\
\hline \multicolumn{4}{|c|}{ at. $\%{ }^{15} \mathrm{~N}$ excess of porewater ammonia } & 0.734 \\
\hline \multicolumn{4}{|c|}{ Relative contribution from roots-rhizomes } & $43.5 \%$ \\
\hline
\end{tabular}

tissues, but only $23.2 \%$ of the ${ }^{15} \mathrm{~N}$ was lost. This difference in losses was partly due to the heterogeneous distribution of ${ }^{15} \mathrm{~N}$ within the plant at the beginning of the field experiment and partly to translocation of ${ }^{15} \mathrm{~N}$ from older to younger tissues. The 3 youngest leaves received ${ }^{15} \mathrm{~N}$, while Leaf No. 4 and rhizome segments R1 to 7 exhibited bi-directional ${ }^{15} \mathrm{~N}$ translocation. Leaves older than No. 4 and the oldest rhizome segments served as ${ }^{15} \mathrm{~N}$ source tissues. There was only a minor net translocation from leaves towards roots-rhizomes. Of the original $342 \mu \mathrm{g}{ }^{15} \mathrm{~N}$ found in the plant $140 \mu \mathrm{g}$ was translocated from older tissues and of this amount $126 \mu \mathrm{g}$ was recovered in younger tissues. Loss of ${ }^{15} \mathrm{~N}$ primarily occurred with shedding of old leaves and loss of old rhizome segments. These losses amounted to $65 \mu \mathrm{g}{ }^{15} \mathrm{~N}$. Unaccounted losses of ${ }^{15} \mathrm{~N}$ (e.g. by leakage) were only $15 \mu \mathrm{g}$, corresponding to $4 \%$ of the original ${ }^{5} \mathrm{~N}$ content in the plant and $10 \%$ of the ${ }^{15} \mathrm{~N}$ lost from old tissues.

Table 3. Zostera marina. Nitrogen incorporation estimates and calculated or measured nitrogen uptake in leaves vs roots of eelgrass. Data from field measurements, a root ${ }^{15} \mathrm{~N}$ uptake experiment and a ${ }^{15} \mathrm{~N}$ pre-incubation experiment. For field data, uptake rates were calculated using the uptake kinetics described by lizumi \& Hattori (1982)

\begin{tabular}{|lccc|}
\hline & $\begin{array}{c}\text { Field } \\
\text { data } \\
\end{array}$ & $\begin{array}{c}\text { Root uptake } \\
\text { experiment } \\
{\left[\mathrm{mg} \mathrm{N}\left(\mathrm{g} \text { dry } \mathrm{wt}^{-1}\right)^{-1} \mathrm{~d}^{-1}\right]}\end{array}$ & $\begin{array}{c}\text { Pre-incubation } \\
\text { experiment }\end{array}$ \\
\hline $\begin{array}{l}\text { N-incorporation } \\
\text { Uptake rates } \\
\text { Leaves }\end{array}$ & 0.22 & 0.34 & 0.29 \\
$\begin{array}{l}\text { Roots-rhizomes } \\
\text { Total plant }\end{array}$ & 0.30 & 0.35 & 0.39 \\
$\begin{array}{l}\text { Roots-rhizomes } \\
\text { contribution } \\
\text { (\% total uptake) }\end{array}$ & 0.47 & 0.33 & 0.17 \\
\hline
\end{tabular}




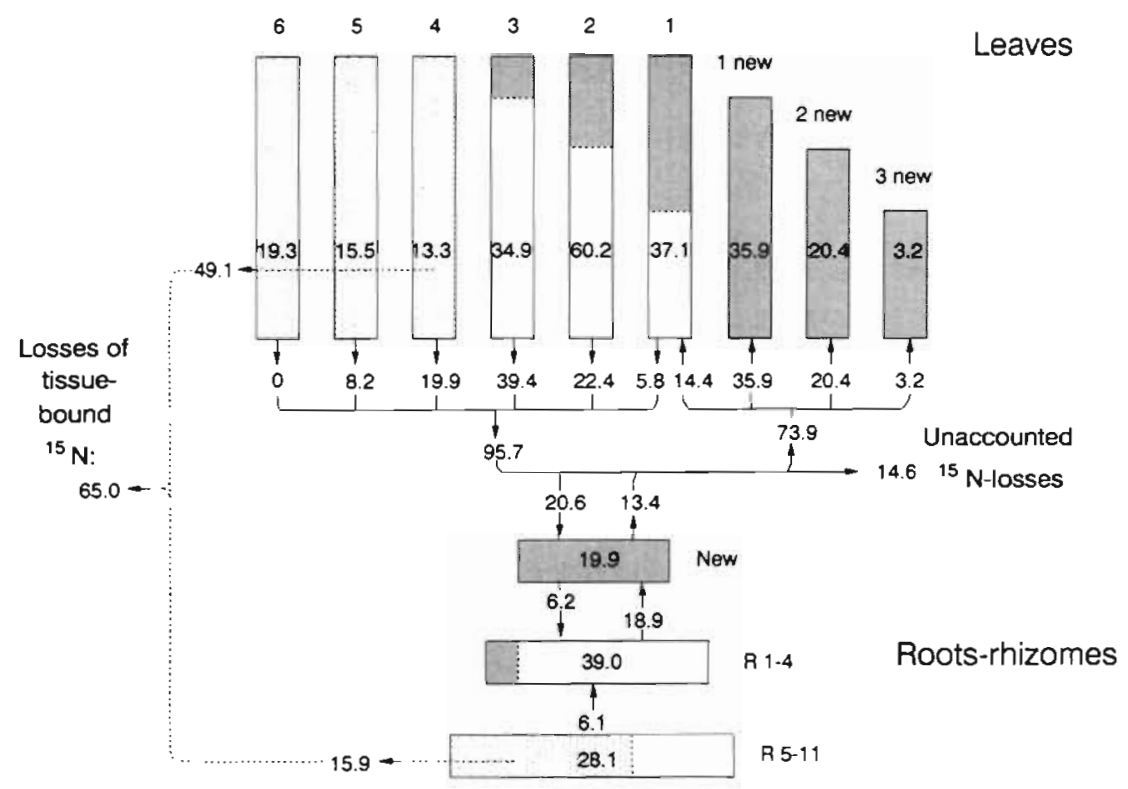

Fig. 2. Zostera marina. ${ }^{15} \mathrm{~N}$ mass balance of plants pre-incubated with ${ }^{15} \mathrm{~N}$ in the laboratory and subsequently transplanted into the eelgrass bed for growth under field conditions. Mass balance covers 27 d growth. Shaded areas: tissues produced; dotted areas: tissues lost during the experiment. Pools are in $\mu \mathrm{g}^{15} \mathrm{~N}$ plant $^{-1}$ and rates in $\mu \mathrm{g}{ }^{15} \mathrm{~N}$ plant ${ }^{-1}(27 \mathrm{~d})^{-1}$

Total-N $\left({ }^{14} \mathrm{~N}+{ }^{15} \mathrm{~N}\right)$ increased from 2913 to $3280 \mu \mathrm{g} \mathrm{N}$ plant ${ }^{-1}$ during the experiment, and incorporation of total- $\mathrm{N}$ in new tissues was $2169 \mu \mathrm{g} \mathrm{N}$ plant ${ }^{-1}$ (Fig. 3). Uptake through leaves and roots-rhizomes was $2215 \mu \mathrm{g}$, more than equalling the $\mathrm{N}$-incorporation of the plant. However, part of the nitrogen taken up in old tissues was translocated to younger leaves and rhizomes, and of a total translocation of $1644 \mu \mathrm{g} \mathrm{N}$ plant $^{-1}$ only $1381 \mu \mathrm{g}$, corresponding to $84 \%$, was recovered in younger tissues leaving an unaccounted loss of $262 \mu \mathrm{g} \mathrm{N}$ plant $^{-1}$. This deficit in the nitrogen budget was covered by reclamation of $275 \mu \mathrm{g} \mathrm{N}$ from old leaves and the oldest rhizomes. Accordingly, nitro- gen reclamation was responsible for $12 \%$ of the total nitrogen incorporation in the plant.

The nitrogen mass balance of individual leaves changed markedly with leaf age (Fig. 4). The highest rate of nitrogen incorporation per biomass unit was found in the youngest leaf. All leaves but the youngest took up nitrogen from the water column, and the younger rapidly growing leaves had higher uptake affinity than older leaves. However, they were not able to cover their nitrogen requirement through uptake but also required translocation from older leaves. Older (greater than No. 3) and non-growing leaves continued to take up nitrogen from the water column,

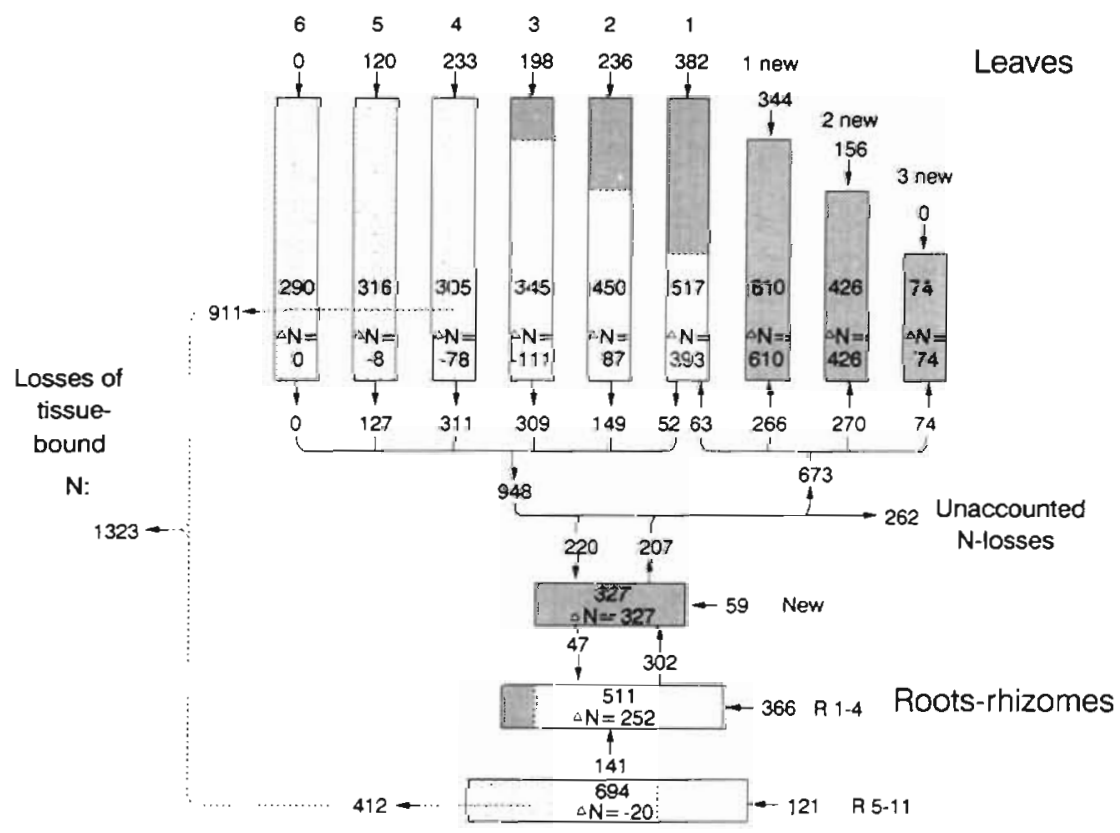

Fig. 3. Zostera marina. Total-N mass balance of plants pre-incubated with ${ }^{15} \mathrm{~N}$ in the laboratory and subsequently transplanted into the eelgrass bed for growth under field conditions. Mass balance covers 27 d growth. Shaded

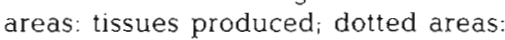
tissues lost during the experiment. Pools are in $\mu \mathrm{g} \mathrm{N} \mathrm{plant}^{-1}$ and rates in $\mu \mathrm{g} \mathrm{N}$ plant $^{-1}(27 \mathrm{~d})^{-1}$ Translocation was calculated from changes in ${ }^{15} \mathrm{~N}$ pools (Fig. 2), and uptake or loss ('unaccounted losses') of nitrogen was calculated from change in nitrogen content of individual tissues and trans. location to or from these tissues. Nitrogen in leaves older than No. 6 and in rhizome segments older than R11 was considered lost from the eelgrass shoot as 'tissue-bound N' 


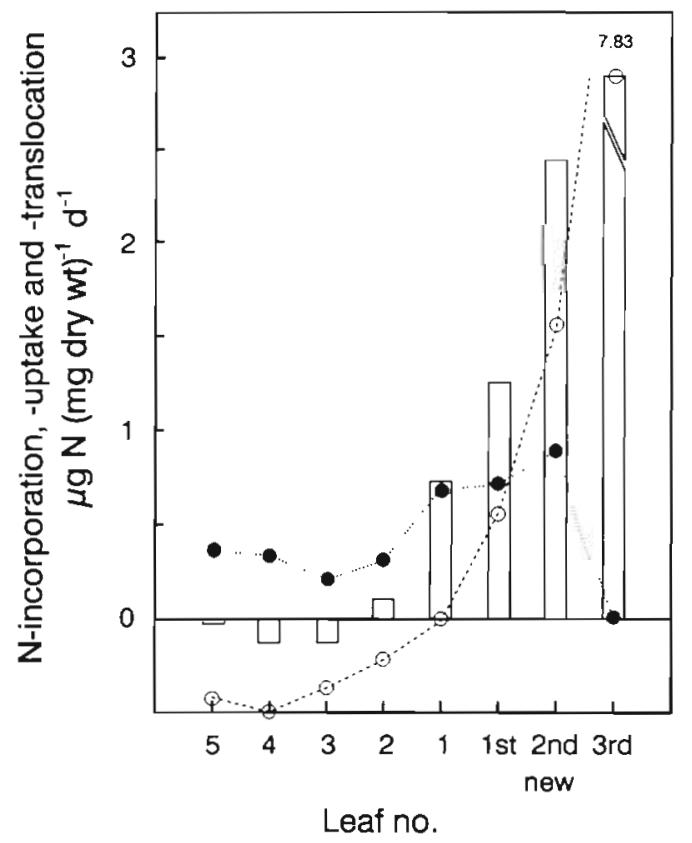

Fig. 4. Zostera marina. N-incorporation (bars), N-uptake $(\bullet \cdots . \cdot)$ and -translocation $(\Theta---\ominus)$ in leaves of different age from plants pre-incubated with ${ }^{15} \mathrm{~N}$ in the laboratory and subsequently transplanted into the eelgrass bed for growth under field conditions

but this recently assimilated nitrogen was translocated to younger tissues together with reclaimed nitrogen. The molar ratio of incorporated $\mathrm{C}$ to incorporated $\mathrm{N}$ was only 14 in the youngest leaf, but this ratio increased rapidly with leaf age, and older leaves started to export nitrogen even before they were fully grown.

\section{DISCUSSION}

During this late summer study period, the relative growth rate of eelgrass plants $\left(0.022 \mathrm{~d}^{-1}\right)$ and the areal production of the eelgrass population $\left(5.6 \mathrm{~g} \mathrm{C} \mathrm{m}^{-2} \mathrm{~d}^{-1}\right)$ were high compared to at other seasons (Pedersen 1990). Similar production rates have been found in other shallow water eelgrass stands (Sand-Jensen 1975, McRoy \& McMillan 1977, Jacobs 1979) and have also previously been measured at our study site (Wium-Andersen \& Borum 1984). The high productivity occurred in spite of relatively low availability of inorganic nitrogen in the water column.

The observed tissue nitrogen contents were in the lower end of the range found in other studies on eelgrass (Harrison \& Mann 1975, Thayer et al. 1977). Average leaf nitrogen content was below the $1.8 \%$ of dry wt reported from an experiment under $\mathrm{N}$-limited growth (Short 1987) and was in a range where eelgrass photosynthesis is positively correlated with leaf nitrogen content (Pedersen 1990). However, the observed concentrations of inorganic nitrogen in the water column and in the sediment should be more than sufficient to saturate eelgrass growth according to values given by Zimmermann et al. (1987) and Dennison et al. (1987). Furthermore, nitrogen availability allowed the plants to increase their internal nitrogen pools during our study period. These observations suggest that eelgrass growth was not severely limited by nitrogen availability, and that evaluation of nutrient limitation solely based on nutrient contents should be done with considerable caution.

Nitrogen incorporation in growing eelgrass tissues was $0.155 \mathrm{~g} \mathrm{~N} \mathrm{~m}^{-2} \mathrm{~d}^{-1}$ and must have been supplied through uptake from the water column and/or sediment porewater and also by reclamation of nitrogen from older tissues (Patriquin 1972, Borum et al. 1989). Porewater concentrations were up to 100 -fold higher than water column concentrations, and, therefore, root uptake could be expected to play the major role in eelgrass nitrogen acquisition. However, the experiment with ${ }^{15} \mathrm{~N}$-enriched sediment showed that less than $50 \%$ of the total gain in plant-bound nitrogen was covered by root uptake. According to the estimates based on the ${ }^{15} \mathrm{~N}$ pre-incubation experiment or calculated from uptake kinetics of inorganic nitrogen (Iizumi \& Hattori 1982), roots were responsible for $24 \%$ and $60 \%$ of the nitrogen incorporation, respectively. The kinetic estimates and our direct determinations support the conclusion that leaves play an important role in uptake of nitrogen even under low nutrient availability in the water column (Iizumi \& Hattori 1982 , Short \& McRoy 1984, Zimmerman et al. 1987).

Borum et al. (1989) suggested that nitrogen conservation (i.e. reclamation) could potentially be an important mechanism for eelgrass nitrogen nutrition, and the present study clearly showed that nitrogen is reclaimed from old tissues and translocated to younger and actively growing plant parts. Nutrient conservation is well known from deciduous trees and terrestrial, evergreen plants living in nutrient-poor environments (e.g. Small 1972, Callaghan 1980, Chapin \& Kedrowski 1983, Aerts 1989, Jonasson 1989, Chapin \& Moilanen 1991) and has also been found in marsh plants (Hopkinson \& Schubauer 1984, Shaver \& Melillo 1984). To our knowledge, nutrient conservation has not previously been shown for submerged macrophytes, although internal distributions of nutritional elements among leaves of different age in eelgrass (Jensen 1915) and in the freshwater isoetid Littorella uniflora (Christiansen et al. 1985) have been reported to indicate nutrient conservation.

Reclamation of nitrogen from old leaves of terrestrial plants varies from a few to more than $90 \%$ of the 
original nitrogen pools (see references above) but most often values are between 30 and $60 \%$ (Jonasson 1989). In our study older eelgrass leaves lost one fourth of their original nitrogen content when changing from position No. 3 to 6 in the short shoot. Of this loss $90 \%$ was recovered in younger tissues. Accordingly, nitrogen reclamation could potentially supply 20 to $25 \%$ of total nitrogen incorporation in younger tissues. However, since the total nitrogen content of eelgrass plants increased substantially during the study period, nitrogen reclamation only supplied $12 \%$ of total nitrogen incorporation. Thus, conservation played a minor role in eelgrass nitrogen nutrition during this time of the year, but conservation may be a more important mechanism in early summer when internal nitrogen pools are higher and external nitrogen availability lower than in late July/beginning of August (Pedersen 1990).

The youngest leaf in the eelgrass short shoot solely relied on nitrogen translocated from older leaves or roots. With increasing leaf age, uptake gradually took over the primary role of nitrogen acquisition from translocation, but the most actively growing leaves were still sinks to translocated nitrogen. Leaves older than No. 3 did not grow and acted as sources of nitrogen. In these leaves nitrogen was taken up from the water column and translocated to other plant parts along with phosphorus and photosynthetic products (Pedersen 1990). Translocation of nitrogen (including reclaimed nitrogen) from old and non-growing eelgrass tissues accounted for ca $50 \%$ of the total plant nitrogen incorporation in growing tissues. Thus, old non-growing leaves function as efficient nursing organs not only with respect to photosynthetic products but also to nutrients.

Reclamation of old nitrogen and efficient translocation of recently assimilated nitrogen from older to younger tissues concentrate nitrogen in the most actively growing parts of the plant. The ratio of incorporated $\mathrm{C}$ to incorporated $\mathrm{N}$ of the youngest leaves $(C: N=14$ ) was only 2 -fold higher than the Redfield ratio estimated for phytoplankton ( $\mathrm{C}: \mathrm{N}=6.6$; Redfield et al. 1963). Even before being fully grown, leaves remobilize and export nitrogen, and therefore the $\mathrm{C}: \mathrm{N}$ ratio for total eelgrass leaf growth was 42 or 6 -fold higher than the Redfield ratio. Seagrasses and other slow-growing marine macrophytes are in general characterized by high $\mathrm{C}: \mathrm{N}$ and $\mathrm{C}: \mathrm{P}$ ratios (Atkinson \& Smith 1984, Duarte 1990). However, internal nutrient concentrations vary substantially among different plant parts, and, therefore, the most physiologically active tissues may have $C: N$ and $C: P$ ratios close to the Redfield ratios in spite of low average nutrient contents in the whole plant. Thus, for the same amount of externally supplied nutrients, macrophyte production (measured as carbon assimilation) may be several-fold higher than phytoplankton production. In this study, eelgrass production would be about 6 times higher than phytoplankton production for the same amount of nitrogen.

In conclusion, eelgrass maintains high rates of production during periods of relatively low nitrogen availability in the water column due to efficient nitrogen uptake from both the water column and sediment and due to nitrogen conservation within the plant. The ratio of incorporated $\mathrm{C}$ to incorporated $\mathrm{N}$ is high, but continuous translocation of nitrogen from old to younger plant parts provides high nitrogen contents in the most actively growing and nutrient-demanding tissues. Eelgrass seems well adapted to nitrogen-poor environments because of the internal conservation of nitrogen, the high ratio of incorporated $\mathrm{C}$ to $\mathrm{N}$, and the supply of nitrogen from sediment porewater. These factors reduce the need for eelgrass nitrogen uptake from the water column in competition with phytoplankters and other phototrophs that may exploit the small pools of available nutrients in the water column more efficiently. We expect that other temperate seagrasses have similar mechanisms for efficient utilization of available nitrogen pools, and we hypothesize that analogous mechanisms may be even more pronounced for phosphorus in tropical seagrasses living in extremely phosphorus-poor environments.

Acknowledgements. We gratefully acknowledge the analytical support provided by Henry Blackburn, University of Aarhus, and by Kit Granby, Marine Pollution Laboratory. We also thank Frederick $T$ Short for critical review of the manuscript. This study was supported by the Danish Agency of Environmental Protection under the 'N, P and Organic Matter Research Programme' and the 'Marine Research Programme in Denmark' M.F.P. was supported by grant \#89-0080 from the Carlsberg Foundation.

\section{LITERATURE CITED}

Aerts, R. (1989). Aboveground biomass and nutrient dynamics of Calluna vulgaris and Molinia caerulea in a dry heathland. Oikos 56: 31-38

Atkinson, M. J., Smith, S. V. (1984). C:N:P ratios of benthic marine plants. Limnol. Oceanogr. 28: 568-574

Barko, J. W., Smart, R. M. (1981). Sediment-based nutrition of submerged macrophytes. Aquat. Bot. 10: 339-352

Boon, P. I. (1986). Nitrogen pools in seagrass beds of Cymodocea serrulata and Zostera capricorni of Moreton Bay, Australia. Aquat. Bot. 25: 1-19

Borum, J., Murray, L., Kemp, M. W. (1989). Aspects of nitrogen acquisition and conservation in eelgrass plants. Aquat. Bot. 35: 289-300

Callaghan, T V (1980). Age-related patterns of nutrient allocation in Lycopodium annotinum from Swedish Lapland. Oikos 35: 373-386 
Carignan, R., Kalff, J. (1980). Phosphorus sources for aquatic weeds: water or sediments? Science 207: 987-988

Chapin, F. S., Kedrowski, R. A. (1983). Seasonal changes in nitrogen and phosphorus fractions and autumn retranslocation in evergreen and deciduous taiga trees. Ecology $64: 376-391$

Chapin, F. S., Moilanen, L. (1991). Nutritional controls over nitrogen and phosphorus resorption from Alaskan birch leaves. Ecology 72: 709-715

Christiansen, R., Friis, N. J. S., Søndergård, M. (1985). Leaf production and nitrogen and phosphorus tissue content of Littorella uniflora (L.) Aschers. in relation to nitrogen and phosphorus enrichment of the sediment in oligotrophic Lake Hampen, Denmark. Aquat. Bot. 23: 1-11

Dennison, W. C., Aller, R. C., Alberte, R. S. (1987). Sediment ammonium availability and eelgrass (Zostera marina) growth. Mar. Biol. 94: 469-477

Duarte, C. (1990). Seagrass nutrient content. Mar. Ecol. Prog. Ser. 67: 201-207

Harrison, P. G., Mann, K. H. (1975). Chemical changes during the seasonal cycle of growth and decay in eelgrass (Zostera marina) on the Atlantic coast of Canada. J. Fish Res. Bd Can. 32: 615-621

Hopkinson, C. S., Schubauer, J. P. (1984). Static and dynamic aspects of nitrogen cycling in the salt marsh graminoid Spartina alterniflora. Ecology 65: 961-969

lizumi, H., Hattori, A. (1982). Growth and organic production of eelgrass (Zostera marina L.) in temperate waters of the Pacific coast of Japan. III. The kinetics of nitrogen uptake. Aquat. Bot. 12: 245-256

Jacobs, R. P. W. M. (1979). Distribution and aspects of the production and biomass of eelgrass, Zostera marina L., at Roscoff, France. Aquat. Bot. 7: 151-172

Jensen, P. B. (1915). Studies concerning the organic matter of the sea bottom. Rep. Dan. Biol. Stn 22: 1-39

Jonasson, S. (1989). Implications of leaf longevity, leaf nutrient re-absorption and translocation for the resource economy of five evergreen plant species. Oikos 56:121-131

McRoy, C. P., McMillan, C. (1977). Production ecology and physiology of seagrasses. In McRoy, C. P., Helfferich, C (eds.) Seagrass ecosystems, a scientific perspective Marcel Dekker, New York, p. 53-88

Patriquin, D. G. (1972). The origin of nitrogen and phosphorus for growth of the marine angiosperm Thalassia testudinum. Mar. Biol. 15: 35-46

This article was presented by Dr G. W. Thayer, Beaufort, N. Carolina, USA
Pedersen, M. F. (1990). Nitrogen dynamics of eelgrass (Zostera marina L.). M.S. thesis, Freshwater-Biological Laboratory, University of Copenhagen

Redfield, A. C., Ketchum, B. A., Richards, F. A. (1963). The influence of organisms on the composition of sea-water In: Hill, M. N. (ed.) The sea, Vol. II. Wiley, London, p. 26-77

Sand-Jensen, K. (1975). Biomass, net production and growth dynamics in an eelgrass (Zostera marina L.) population in Vellerup Vig, Denmark. Ophelia 14: 185-201

Sand-Jensen, K., Borum, J. (1991). Ecology and interactions among phototrophic communities in temperate regions. Aquat. Bot. 41. 137-175

Shaver, G. R., Melillo, J. M. (1984). Nutrient budgets of marsh plants: efficiency concepts and relation to availability. Ecology 65: 1491-1510

Short, F. T., McRoy, C. P. (1984). Nitrogen uptake by leaves and roots of the seagrass Zostera marina L. Bot. Mar. 27: $547-555$

Short, F. T (1987). Effects of sediment nutrients on seagrassses: literature review and mesocosm experiments. Aquat. Bot. 27: 41-67

Small, E. (1972). Photosynthetic rates in relation to nitrogen recycling as an adaption to nutrient deficiency in peat bog plants. Can. J. Bot. 50: 2227-2233

Solorzano, L. (1969). Determination of ammonia in natural waters by the phenolhypochlorite method. Limnol. Oceanogr. 14: 799-801

Strickland, J. D. H., Parsons, T R. (1968). A practical handbook of seawater analysis. Bull. Fish. Res. Bd Can. 167

Thayer, G. W., Engel, D. W., LaCroix, M. W. (1977). Seasonal distribution and changes in the nutritive quality of living, dead and detrital fractions of Zostera marina L. J. exp. mar. Biol. Ecol. 30: 109-127

Thursby, G. B., Harlin, M. M. (1982). Leaf-root interaction in the uptake of ammonia by Zostera marina. Mar. Biol. 72: $109-112$

Wium-Andersen, S., Borum, J. (1984). Biomass variation and autotrophic production of an epiphyte-macrophyte community in a coastal Danish area: I. Eelgrass (Zostera marina L.) biomass and net production. Ophelia 23: 33-46

Zimmerman, R. C., Smith, R. D., Alberte, R. S. (1987). Is growth of eelgrass nitrogen limited? A numerical simulation of the effects of light and nitrogen on the growth dynamics of Zostera marina. Mar. Ecol. Prog. Ser. 41: $167-176$

Manuscript first received: August 1, 1991

Revised version accepted: January 17, 1992 